\title{
Obesity and metabolic syndrome in children: what's new?
}

\section{Mini review}

Obesity is increasing worldwide and has emerged as an epidemic affecting all ages and young people are not an exception. ${ }^{1-4}$ The childhood obesity has become a major health concern in recent decades, in particular regarding to future cardiovascular disease and certain types of cancer. ${ }^{5}$ Its rising prevalence has led to a parallel rise of the so-called metabolic syndrome ${ }^{6,7}$ That's well established that the nowadays lifestyle accounts for a serious part of this burden, but there are still some doubts about the role of genetic imprinting, adipokines, 25-hydroxyvitamin D $(25[\mathrm{OH}] \mathrm{D})$, hepatic fat infiltration and puberty.

The increase of visceral adipose tissue and its secretory products (adipokines) are believed to play a major role in the determination of insulin resistance. ${ }^{8}$ Recent evidence suggests a relationship between leptin levels and energy balance in obese children. ${ }^{9-11}$ Adiponectin is related to obesity and insulin resistance and appears to be the strongest predictor for metabolic syndrome, even in children, but its role still remains controversial. ${ }^{12,13}$ Ghrelin, a somatotropic and orexigenic hormone has also been recognized as an important regulator of energy metabolism. ${ }^{14}$ It's important to notice that the amount of brown(BAT) and white adipose tissue (WAT) has to be considered, as well as their ability to transdifferentiate. They present two opposite functions both essential for survival: white adipocytes store energy released between meals and the brown ones burn lipids to maintain thermogenesis. ${ }^{15}$ Some genes are specific for each cell type; UCP1 is restricted to $\mathrm{BAT}^{16}$ and leptin is absent from classic multilocular brown adipocytes. ${ }^{17}$ Over the last decades, the adipose organ has gained particular interest as an endocrine organ and a potential target to new therapeutic strategies, as browning could be harnessed to tackle obesity and metabolic syndrome. ${ }^{18,19}$

Another hot topic is about the $25[\mathrm{OH}]$ D..$^{20-22}$ Poor vitamin D status has been associated with future risk of type 2 diabetes and metabolic syndrome in the obese. ${ }^{23,24}$ This relationship may be explained by vitamin D's preferred deposition in body fat, making it unavailable for use by other tissues. ${ }^{25}$ However, these findings must be interpreted in a surface including effects of pubertal status, presence of nonalcoholic fatty liver disease (NAFLD), PTH status and magnesium levels. ${ }^{26-29}$ NAFLD is defined by hepatic fat infiltration in the absence of other excessive alcohol intake, viral, autoimmune and drug-induced liver disease. ${ }^{30,31}$ Its prevalence has been reported about $53 \%$ in obese children. ${ }^{32}$ It's interesting to notice that Pirgon et al., ${ }^{33}$ found that vitamin D status was negatively correlated with HOMA-IR in those with NAFLD but not in those without it, suggesting that there's a crosstalk between several pathways. Adipocytokines seem also to play a role about the vitamin D status Walker et al. ${ }^{34}$

Identified adiponectin as a key regulatory protein in the link between vitamin D deficiency and pediatric obesity but the mechanism they interact has not been elucidated. By contrast, Belenchia et al., ${ }^{35}$ did not find any changes in adiponectin in obese adolescents supplemented with vitamin D but observed a significant decrease in leptin to adiponectin ratio and that correcting vitamin D
Volume 4 Issue 3 - 2017

\author{
Menezes Nunes J,' Medina JL, ${ }^{2}$ Santos AC, ${ }^{3}$ \\ Barros $\mathrm{H}^{3}$ \\ 'Luz Saude Private Hospitals, Institute of Public Health of the \\ University of Porto (ISPUP), Portugal \\ ${ }^{2}$ Faculty of Medicine, Porto University, Portugal \\ ${ }^{3}$ Instituto de Investigacao e Inovacao em Saude, Portugal
}

Correspondence: Joana Menezes Nunes, Luz Saude Private Hospitals, Institute of Public Health of the University of Porto (ISPUP), Portugal, Rua Alberto Serpa nr I50/I52, 4100-0 I0 Porto, Tel +351 91 6462294 ,

Email joana.maria.menezes@gmail.com

Received: February 13,2017 | Published: April 03, 2017

status of obese adolescents improved insulin sensitivity with results being similar to metformin. It is important to underline that calcitriola is a strong immunomodulator and improves systemic inflammation, which usually accompanies obesity, hyperinsulinemia and eventually beta-cell dysfunction. ${ }^{23}$

Excess adiposity may also influence various aspects of pubertal development and be influence by pubertal timing. Some studies are inconclusive ${ }^{36-38}$ while others found age at menarche to be inversely associated with adiposity in childhood. ${ }^{39-41}$ Recent papers suggested that a history of early menarche may help to identify women at risk for metabolic syndrome ${ }^{42}$ and that it may play a role in the development of prediabetes and diabetes independently of body mass index. ${ }^{43}$ However, little is known about the underlying genetics of pubertal timing, childhood obesity and metabolic syndrome. Five loci are associated with pubertal timing (near MAPK3, PXMP3, VGLL3, ADCY3-POMC and LIN28B), all impacting multiple aspects of growth. ${ }^{44} \mathrm{~A}$ novel variant was found to correlate with the expression of MAPK3 and to be associated with increased prepubertal growth and earlier menarche. ${ }^{44}$ Another variant near ADCY3-POMC has been implicated in childhood ${ }^{45}$ and adulthood obesity, ${ }^{46}$ reduced pubertal growth and earlier puberty. ${ }^{44,45}$ Also, rare recurrent copy number variations near MAPK3 on chromosome 16 p11.2 have been shown to be associated with early onset obesity. ${ }^{47,48}$

Recently, the concept of metabolic endotoxaemia (an increase in plasma lipopolysaccharide levels, caused by changes in the composition of the gut-microbiota and gut barrier dysfunctions) has gained attention as one of the triggering factors responsible for the development of insulin resistance, obesity, metabolic dysfunction and low-grade chronic inflammation ${ }^{49,50}$ and some authors believe that there's a crosstalk between numerous organs (gut, adipose tissue, muscles, liver, bone and brain), ${ }^{49}$ all acting together in a genetic background susceptibility. 
A better understanding of the possible biological mechanisms related to the occurrence of metabolic syndrome in children is of major interest as they are usually treatment naïve and otherwise relatively free of co-morbidities, allowing studying the sequence of events of obesity-related pathology. Therefore, efforts to identify children and adolescents at risk earlier in life are very important in order to target them for anti obesity strategies and provide benefit from preventive interventions.

\section{Acknowledgements}

None.

\section{Conflicts of interest}

The author declares there is no conflict of interest.

\section{References}

1. Kiess W, Galler A, Reich A, et al. Clinical aspects of obesity in childhood and adolescence. Obes Rev. 2001;2(1):29-36.

2. Berenson GS. Obesity-a critical issue in preventive cardiology: the Bogalusa Heart Study. Prev Cardiol. 2005;8(4):234-241.

3. Mello MM, Studdert DM, Brennan TA. Obesity-the new frontier of public health law. $N$ Engl J Med. 2006;354(24):2601-2610.

4. Wang Y, Lobstein T. Worldwide trends in childhood overweight and obesity. Int J Pediatr Obes. 2006;1(1):11-25.

5. Burt Solorzano CM, McCartney CR. Obesity and the pubertal transition in girls and boys. Reproduction. 2010;140(3):339-410.

6. Cruz M, Torres M, Aguilar-Herrera B, et al. Type 2 diabetes mellitus in children - an increasing health problem in Mexico. J Pediatr Endocrinol Metab. 2004;17(2):183-190.

7. Flores-Huerta S, Klunder-Klunder M, Reyes-de-la-Cruz L, et al Increase in body mass index and waist circumference is associated with high blood pressure in children and adolescents in Mexico City. Arch Med Res. 2009;40(3):208-215.

8. Fruhbeck G, Gomez-Ambrosi J, Muruzabal FJ, et al. The adipocyte: a model for integration of endocrine and metabolic signaling in energy metabolism regulation. Am J Physiol Endocrinol Metab. 2001;280(6):E827-E847.

9. Lammert A, Kiess W, Böttner A, et al. Soluble leptin receptor represents the main leptin binding activity in human blood. Biochem Biophys Res Commun. 2001;283(4):982-988.

10. Zastrow O, Seidel B, Kiess W, et al. The soluble leptin receptor is crucial for leptin action: evidence from clinical and experimental data. Int J Obes Relat Metab Disord. 2003;27(12):1472-1478.

11. Korner A, Kratzsch J, Gausche R, et al. New predictors if the metabolic syndrome in children - role of adipocytokines. Pediatr Res. 2007;61(6):640-645.

12. Cizmecioglu FM, Etiler N, Ergen A, et al. Association of adiponectin, resistin and high sensitive CRP level with the metabolic syndrome in childhood and adolescence. Exp Clin Endocrinol Diabetes. 2009; 117(10):622-627.

13. Snehalatha C, Yamuna A, Ramachandran A. Plasma adiponectin does not correlate with insulin resistance and cardiometabolic variables in nondiabetic Asian Indian teenagers. Diabetes Care. 2008;31(12) 2374-2379.

14. Vendrell J, Broch M, Vilarrasa N, et al. Resistin, adiponectin, ghrelin, leptin and proinflammatory cytokines: relationships in obesity. Obes Res. 2004;12(6):962-971.
15. Giordano A, Smorlesi A, Frontini A, et al. White, brown and pink adipocytes: the extraordinary plasticity of the adipose organ. Eur $J$ Endocrinol. 2014;170(5):R159-R171.

16. Cannon B, Nedergaard J. Brown adipose tissue: function and physiological significance. Physiol Rev. 2004;84(1):277-359.

17. Cinti S, Frederich RC, Zingaretti MC, et al. Immunohistochemical localization of leptin and uncoupling protein in white and brown adipose tissue. Endocrinology. 1997;138(2):797-804.

18. Nedergaard J, Bengtsson T, Cannon B. New powers of brown fat: fighting the metabolic syndrome. Cell Metab. 2011;13(3):238-240.

19. Stanford KJ, Middelbeek RJ, Townsend KL, et al. Brown adipose tissue regulates lucose homeostasis and insulin sensitivity. J Clin Invest. 2013;123(1):215-223.

20. Chiu KC, Chu A, Go VL, et al. Hypovitaminosus D is associated with insulin resistance and beta cell dysfunction. Am J Clin Nutr 2004;79(5):820-825.

21. Ford ES, Ajani UA, McGuire LC, et al. Concentrations of serum vitamin D and the metabolic syndrome among US adults. Diabetes Care. 2005;28(5):1228-1230

22. Sun G, Vasdev S, Martin GR, et al. Altered calcium homeostasis is correlated with abnormalities of fasting serum glucose, insulin resistance and beta-cell dysfunction in the Newfoundland population. Diabetes. 2005;54(11):3336-3339.

23. Peterson CA, Tosh AK, Belenchia AM (2014) Vitamin D insufficiency and insulin resistance in obese adolescents. Ther Adv Endocrinol Metab. 2014;5(6):166-189.

24. Pittas AG, Lau J, Hu FB, et al. The role of vitamin D and calcium in type 2 diabetes-a systematic review and meta-analysis. $J$ Clin Endocrinol Metab. 2007;92(6):2017-2029.

25. Blum M, Dolnikowski G, Seyoum E, et al. Vitamin D(3) in fat tissue Endocrine. 2008;33(1):90-94.

26. Kramer CK, Swaminathan B, Hanley AJ, et al. Prospective associations of vitamin D status with beta-cell function, insulin sensitivity and glycemia: the impact of parathyroid hormone status. Diabetes. 2014;63(11):3868-3879.

27. Reis JP, Von MD, Miller ER. Relation of 25-hydroxyvitamin D and parathyroid hormone levels with metabolic syndrome among US adults. Eur J Endocrinol. 2008;159(1):41-48.

28. Roislien J, Calseter BV, Hjelmesaeth J. Parathyroid hormone is a plausible mediator for the metabolic syndrome in the morbidly obese: a cross-sectional study. Cardiovasc Diabetol. 2011;10:17.

29. Reinehr T, De SG, Alexy U, et al. Vitamin D status and parathyroid hormone in obese children before and after weight loss. Eur J Endocrinol. 2007; 157(2):225-232.

30. Siegel AB, Zhu AX. Metabolic syndrome and hepatocellular carcinoma: two growing epidemics with a potential link. Cancer. 2009;115(24):5651-5661

31. Valenti L, Dongiovanni P, Fargion S. Diagnostic and therapeutic implications of the association between ferritin level and severity of nonalcoholic fatty liver disease. World $J$ Gastroenterol. 2012;18(29):3782-3786.

32. Dowman JK, Tomlinson JW, Newsome PN. Pathogenesis of non-alcoholic fatty liver disease. QJM. 2010;103(2):71-83.

33. Pirgon $\mathrm{O}$, Cekmez F, Bilgin $\mathrm{H}$, et al. Low 25-hydroxyvitamin D level is associated with insulin sensitivity in obese adolescents with nonalcoholic fatty liver disease. Obes Res Clin Pract. 2013;7(4):E275E283. 
34. Walker G, Ricotti R, Roccio M, et al. Pediatric obesity and vitamin D deficiency: a proteomic approach identifies multimeric adiponectin as a key link between these conditions. PLoS One. 2014;9(1):e83685.

35. Belenchia A, Tosh A, Hillman L, et al. Correcting vitamin D insufficiency improves insulin sensitivity in obese adolescents: a randomized controlled trial. Am J Clin Nutr. 2013;97(4):774-781.

36. Cho GJ, Park HT, Shin JH, et al. The relationship between reproductive factors and metabolic syndrome in Korean postmenopausal women: Korea National Health and Nutrition Survey 2005. Menopause. 2009;16(5):998-1003.

37. Feng Y, Hong X, Wilker E, et al. Effects of age at menarche, reproductive years and menopause on metabolic risk factors for cardiovascular diseases. Atherosclerosis. 2008;196(2):590-597.

38. Frontini MG, Srinivasan SR, Berenson GS. Longitudinal changes in risk variables underlying metabolic Syndrome X from childhood to young adulthood in female subjects with a history of early menarche: the Bogalusa Heart Study. Int J Obes Relat Metab Disord. 2003;27(11):1398-1404.

39. Kivimaki M, Lawlor DA, Smith GD, et al. Association of age at menarche with cardiovascular risk factors, vascular structure and function in adulthood: the Cardiovascular Risk in Young Finns Study. Am J Clin Nutr. 2008;87(6):1876-1882.

40. Freedman DS, Khan LK, Serdula MK, et al. The relation of menarcheal age to obesity in childhood and adulthood: the Bogalusa heart study. BMC Pediatr. 2003;3:3.

41. Pierce MB, Leon DA. Age at menarche and adult BMI in the Aberdeen children of the 1950s cohort study. Am J Clin Nutr. 2005;82(4):733-739.
42. Stöckl D, Meisinger C, Peters A, et al. Age at menarche and its association with metabolic syndrome and its components: results from the KORA F4 Study. PLoS One. 2011;6(10):e26076.

43. Stöckl D, Döring A, Peters A, et al. Age at menarche is associated with prediates and diabetes in women (aged 32-81 years) from the general population: the KORA F4 Study. Diabetologia. 2012;55(3):681-688.

44. Cousminer DL, Berry DJ, Timpson NJ, et al. Genome-wide association and longitudinal analyses reveal genetic loci linking pubertal height growth, pubertal timing and childhood adiposity. Hum Mol Genet. 2013;22(13):2735-2747.

45. Bradfield JP, Taal HR, Timpson NJ, et al. A genome-wide association meta-analysis identifies new childhood obesity loci. Nat Genet. 2012;44(5):526-531.

46. Speliotes EK, Willer CJ, Berndt SI, et al. Association analyses of 149,796 individuals reveal 18 new loci associated with body mass index. Nat Genet. 2010;42(11):937-948.

47. Walters RG, Jacquemont S, Valsesia A, et al. A new highly penetrant form of obesity due to deletions on chromosome 16p11.2. Nature. 2010;463(7281): 671-675.

48. Jacquemont S, Reymond A, Zufferey F, et al. Mirror extreme BMI phenotypes associated with gene dosage at the chromosome $16 \mathrm{p} 11.2$ locus. Nature. 2011;478(7367):97-102.

49. Geurts L, Neyrinck AM, Delzenne NM, et al. Gut microbiota controls adipose tissue expansion, gut barrier and glucose metabolism: novel insights into molecular targets and interventions using prebiotics. $\mathrm{Be}$ nef Microbes. 2014;5(1):3-17.

50. Sanz Y, Moya-Pérez A. Microbiota, inflammation and obesity. Adv Exp Med Biol. 2014;817:291-317. 